\title{
Experimental Transmission of Enterobacter cloacae from Fishes to Wounds of Skin by Using balb/c Mice
}

\author{
Sabaa Hilal Hadi \\ Department of Microbiology, College of Veterinary Medicine, Al-Qasim green university, Iraq.
}

\begin{abstract}
Often, housewives are injured in the hands, which may expose them to infection, possibly with different diseases, when they are exposed as is the case in this study, which was dependent for isolation, identification of Enterobacter cloacae from different healthy fishes and experimental infection for bacteria in mice. The thirty clinical specimens were collected from fishes is diagnosed according cultural and biochemical tests as well as the central health laboratories/enterobacterial unit/Bagdad. The Murine Model of Wound E. cloacae Infection were done with $2 \times 10^{5}$ $\mathrm{ID}_{50} \mathrm{CFU} / \mathrm{ml}$ and the bacteria was isolated from infected mice group to different organs with high prevalence result of $100 \%$ percent from intestine, duodenum and blood, the spleen and liver give percentage $83 \%$ from bacteria with smallest prevalence from heart $66 \%$ and brain $50 \%$ respectively, the pathogenicity will be study and all infected group give positive results.
\end{abstract}

Keywords: Enterobacter cloacae, Fishes, Skin.

*Correspondence: imadbiotechnology@gmail.com

(Received: 26 September 2018; accepted: 03 November 2018)

Citation: Sabaa Hilal Hadi, Experimental Transmission of Enterobacter cloacae from Fishes to Wounds of Skin by Using balb/c Mice, J Pure Appl Microbiol., 2018; 12(4):2117-2121. http://dx.doi.org/10.22207/JPAM.12.4.49

(c) The Author(s) 2018. Open Access. This article is distributed under the terms of the Creative Commons Attribution 4.0 International License which permits unrestricted use, sharing, distribution, and reproduction in any medium, provided you give appropriate credit to the original author(s) and the source, provide a link to the Creative Commons license, and indicate if changes were made. 


\section{INTRODUCTION}

The family Enterobacteriaceae have members of genus Enterobacter such as E. cloacae are act as opportunistic human pathogens; This organism is an opportunistic pathogen, which means that the disease targets compromised patients such as the young, old, or those that have a severe disease such as human immunodeficiency virus $^{1}$. Nosocomial infections are most frequent from these bacteria, which means it may be contracted from the result of being hospitalized or debilitated patients, and investigation of Enterobacter cloacae infections at a small animals veterinary teaching hospital ${ }^{2}$. A National Nosocomial Infection Surveillance System (NNIS) study found that Enterobacter accounts for 5 to $11 \%$ of all nosocomially transmitted blood products, wound that have been isolated from hands of personnel, and respiratory tract and urinary tract infections ${ }^{3}$. Many genera of Enterobacteriaceae such as Escherichia, Enterobacter, Klebsiella and Serratia have been implicated in a broad range of clinical syndromes bacteremia and infections of skin and soft tissues as well as fruits, vegetables, and devices such as a hot water treatment tank, respiratory tract, urinary tract, bone and joints, central nervous system, gastro-intestinal tract, and other organs ${ }^{4}$. Enterobacter cloacae, Enterobacter sakazakii, and Enterobacter hormaechei have caused sepsis and a severe form of necrotizing meningitis in neonates ${ }^{5}$. Enterobacter spp. are facultative anaerobic gram - negative bacilli means they contain two cell membranes, $80 \%$ are capsulated, most species are uses its peritrichous flagella for movement and have class 1 fimbriae ${ }^{1}$. Enterobacter cloacae and Enterobacter aerogenes are part of the normal flora of the gastrointestinal tract and are found in a high proportion of sewage sample, at concentrations of up to $10^{7}$ organism g- $1^{1}$. In extra intestinal infections Enterobacter are involved, which are known to possess virulence associated characteristics, they have the ability to adhere to and invade eukaryotic cells, which can cause toxins to run in the tissues and blood stream, once outside the gastrointestinal tract, they would take advantage of being able to chelate iron to survive and spread within the host ${ }^{7} . E$. cloacae infections have the highest mortality rate compared to other Enterobacter infections ${ }^{8}$.

\section{MATERIALS AND METHODS}

Samples collection: A total 30 different specimens were collected from ten Tilapia and Liza abu fishes bought from locale market in Alqasim city during December 2017 (IRAQ), A different samples from (mucus of skin, viscera fluid, gill, kidney, muscle, eyes and blood) were cultured in nutrient agar after that transferred to selective media XLD,SS media for Morphological characteristics of colonies as primary identification of Entrobacter cloacae according to the criteria of 9,10 .

\section{Preparation of bacteria inoculum}

Samples of bacteria tested by gram stain for studying the microscopic properties under the oiled lens of light microscope, for ensuring diagnosis we sent to the central health laboratories/enterobacterial unit/Bagdad.

Grow the bacteria at $37^{\circ} \mathrm{C}$ with brain heart infusion broth for $12 \mathrm{hr}$. then collect bacteria by centrifugation $(3000 \mathrm{rpm} / \mathrm{min}$ for 15 $\min , 20^{\circ} \mathrm{C}$ ). Wash bacteria three times in an equal volume sterile PBS and harvest by centrifugation. Resuspend bacteria two- fold dilution in PBS to attain a final concentration of $2 \times 10^{5}$ colonyforming unit(CFU)/ml.

Infectious dose (ID50) calculated by the two-fold dilutions by applied in six mice group for used later in Murine Model of Wound Infection.

\section{Preparation of Mice for infection}

Twelve male 1 mounths old mice (balb/c) examined with negative culture $E$. cloacae in feces. Later, used in Murine model of wound infection divided into two groups the first group contain six mice for test and the second group contain six mice as control group ${ }^{11}$.

Mice are shaved by Casanova ${ }^{\circledR}$ hair remove spry to inoculation bacteria, all mouse procedures are performed under local lidocaine anesthesia.

Pinch the skin by Miltex ${ }^{\circledR}$ standard biopsy punch of the prepared site of infection, inoculate the animals subcutaneously with $0.05 \mathrm{ml}$ of $2 \times 10^{5}$ live $E$. cloacae or sterile saline. Monitoring the course of infection on 2-3 days archives for 6 days.

The infected mice were dissected and the samples was taken from many organs (blood, brain, heart, spleen, intestine and duodenum) for isolated bacteria. The control group were also tested from bacteria. 


\section{The statistical analysis}

Statistical analyses were carried out using chi-square tests of the SPSS software version 9.0 for windows (Levesque 2007) to compare the rate of isolation of bacteria among different organs. The differences were considered significant at $p<0.05$.

\section{RESULTS AND DISCUSSION \\ Isolation of associated bacteria}

The results were specified of thirty samples of Entrobacter cloacae from fishes give positive culture and appeared under the microscope in oil emersion 100x magnification (Picture No1). Salmonella Shigella (SS) agar the bacteria appear as small pink colonies, that were round, dark center, slightly mucoid and 2-3 mm in diameter, with regular edges. (Picture No2). The $E$. cloacae was isolated later from anatomical infected mice appeared in a nutrient agar as a yellowish pale, that were large flat mucus colonies with irregular edges. and the control group were gives negative results.

Table 1. Enterobacter cloacae isolated from internal organs $(n=48)$ of mice.

\begin{tabular}{lcc}
\hline $\begin{array}{l}\text { Isolated } \\
\begin{array}{l}\text { E. cloacae } \\
\text { bacteria }\end{array}\end{array}$ & $\begin{array}{c}\text { No. of positive } \\
\text { samples and } \\
\text { prevalence }(\%) \\
(\mathrm{n}=60)\end{array}$ & $\begin{array}{c}\text { Total } \\
\text { No. } \\
(\%)\end{array}$ \\
\hline Intestine & $6(60)$ & $(100 \%)$ \\
Duodenum & $6(60)$ & $(100 \%)$ \\
Blood & $6(60)$ & $(100 \%)$ \\
Spleen & $5(50)$ & $(83 \%)$ \\
Liver & $5(50)$ & $(83 \%)$ \\
Heart & $4(40)$ & $(66 \%)$ \\
Brain & $3(30)$ & $(50 \%)$ \\
eye & $\mathrm{NI}$ & $\mathrm{NI}$ \\
\hline
\end{tabular}

Legend: NI- Not identified

\section{Application the murine test}

The Murine model of wound E. cloacae infection mice were injection with live $E$. cloacae or sterile saline show picture No3 by: Remove hair from dorsal side of mice, Euthanized mice $1.5 \times 1.5$ $\mathrm{cm}$-tissue full thickness punch surgical wound covered with plaster, Inject subcutaneously with $0.05 \mathrm{ml}$ of $2 \times 10^{5}$ (CFU) E. cloacae under plaster.

Isolation of bacterial from internal organs of mice: The $E$. cloacae isolated from the internal organs of infected mice were identified in (Table 1).

Prevalence of bacteria in different internal organs of mice: From the collected samples $(n=6)$, E. cloacae was isolated (100\%) percentage from 6 mice intestine, Similarly, the overall prevalence of duodenum, and blood organs whereas $E$. cloacae was found in 5 cases (83\%) of spleen and liver, also the bacteria could be isolated from heart (66\%) cases, the brain give $(50 \%)$ from total number, respectively. The results have been notable that all seven different organs could be isolated the bacteria. No E. cloacae could be isolated from eyes samples. The control group give negative result in culture media. Intestine, duodenum, and blood was the most prevalent region in all types of samples in this study (Table 1).

Pathogenicity test of $E$. cloacae in mice: Pathogenicity test of $E$. cloacae was calculated throw the murine test when inoculation bacteria for mice (Table 2). The experimental mice were infected with positive grow in culture media within $48 \mathrm{hrs}$ and no clinical signs noted, whereas the control mice give negative result. Thus, the isolates were categorized as pathogenic. Enterobacter cloacae have been considered as opportunistic pathogens involved in a broad array of infections, the study focused on explaining the contribution of transmission activity, as well as the analysis of incidence of light microscope rod-shape bacterial

Table 2. Pathogenicity test of E. cloacae

\begin{tabular}{lcccc}
\hline Group & $\begin{array}{c}\text { Rout of } \\
\text { inoculation }\end{array}$ & $\begin{array}{c}\text { Number of mice } \\
\text { inoculation }\end{array}$ & $\begin{array}{c}\text { Number of mice } \\
\text { infected within 48hrs. }\end{array}$ & Inter-pretation \\
\hline Test & subcutaneous & 6 & 6 & $\mathrm{P}$ \\
control & subcutaneous & 6 & 0 & $\mathrm{NP}$ \\
\hline
\end{tabular}

Legend: $P=$ Pathogenic, $N P=$ Nonpathogenic. 


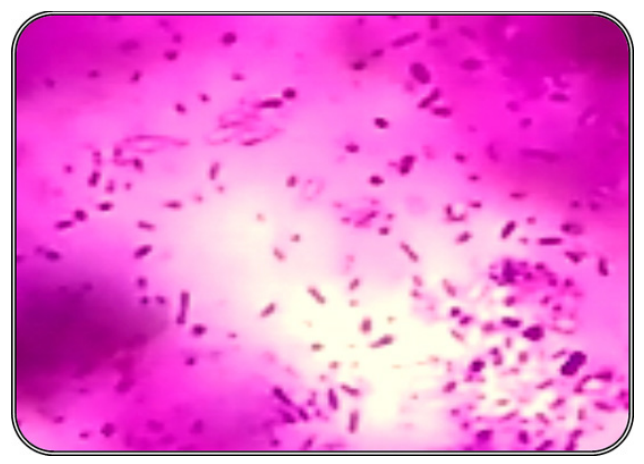

Fig. 1. Gram- negative bacilli of Entrobacter cloacae bacteria
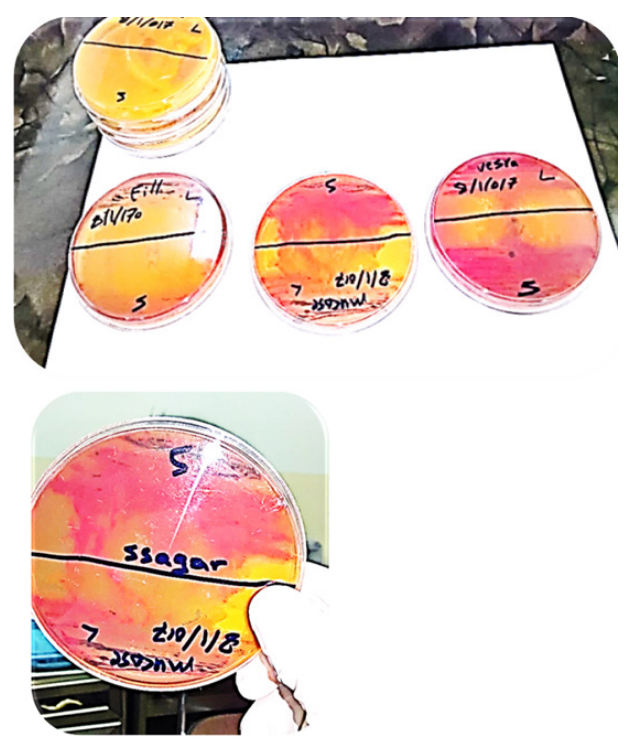

Fig. 2. Pink, round and black center bacteria from mucus, viscera, and gill samples cultures in SS agar.
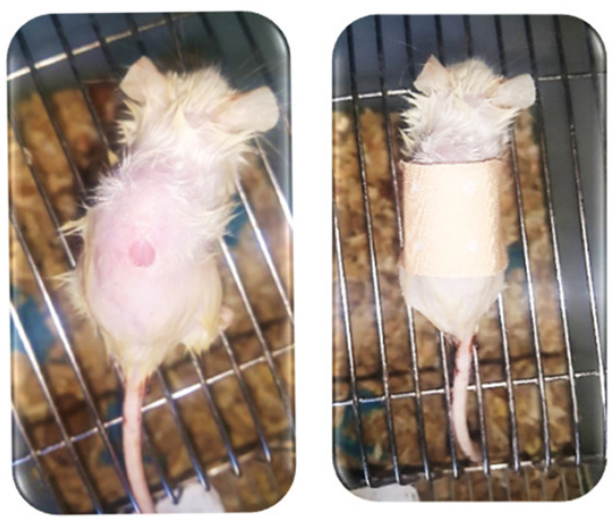

Fig. 3. Murine test: a/ $1.5 \times 1.5 \mathrm{~cm}$-tissue full thickness Miltex ${ }^{\circledast}$ standard biopsy punch surgical skin wound. b/ plaster covered wound. compression with (Sylwia, et al. 2009) that studies of cell morphology in a scanning electron microscope (SEM) with needle-like structures cell. Enterobacter, joins the genera Klebsiella and Serratia in the tribe Klebsiellae ${ }^{12}$ Colonies of Enterobacter strains may be slightly mucoid. In the present study, eight different internal organs (intestine, duodenum, blood, spleen, liver heart, brain and eyes) of mice were could be isolated bacteria from it. This is in line of findings by Azza $\mathrm{H}$ et al. (2012) ${ }^{13}$ when isolated from Mugil capito fish, considering all the 48 samples, E. cloacae was highly prevalent $(100 \%)$ in intestine, duodenum, and blood, whereas highly prevalent in spleen and liver $(83 \%)^{14}$. Studied the prevalence of $E$. coli in broiler feces and found $65 \%$ prevalence which is lower than that of the present study. ${ }^{15}$ Reported a $30.55 \%$ prevalence of Salmonella spp. In poultry meat which is lower than that of the present study. The pathogenicity test for all the isolated E. cloacae revealed that all. were pathogenic. ${ }^{16}$ reported that more than one predisposing factors such as environmental and managemental factors (housing, climate etc), imbalance nutrition and immune status of the poultry might play roles in developing diseases while harboring the potential pathogenic bacteria. A mouse model can be used to investigate a number of factors related to the pathogenesis of skin and soft tissue infections, including the contribution of specific bacterial molecules to disease with virulence strain, and agree with ${ }^{17}$ that understand staphylococcal pathogenesis as a human pathogen when determine many factors like environmental changes and produce a variety of elements that make to virulence by used a mouse as model. ${ }^{18}$ skin infections are caused by a taxonomic diversity of infectious microorganisms that include fungi, viruses.

\section{ACKNOWLEDGEMENTS}

We gratefully acknowledge the all kind of technical supports from the Department of Microbiology, College of Veterinary Medicine, AlQasim green university, Iraq.

\section{REFERENCES}

1. Hopley, L. and Schalkwyk, J. “Enterobacter.2001. 2. Weese, J.S. Investigation of Enterobacter cloacae infections at a small animal veterinary teaching 
hospital. 2008; 130(3-4): 426-8.

3. Irina, K.M. Transfusion Medicine and Hemostasis (Second Edition), 2013ALS Environmental are one of the first UK laboratories to validate and have accredited to ISO 17025.2005.

4. Hart, C.A. Klebsiella, Citrobacter, Enterobacter and Serratia spp. In S. H. Gillespie and P. M. Hawkey ( eds. ), Principles and practice of clinical bacteriology, England, UK : John Wiley and Sons Ltd. , 2nd ed. 2006.

5. Victor, N. and Jerome, O. Klein, in Infectious Diseases of the Fetus and Newborn (Seventh Edition 129-134).2011.

6. Farmer, J.J., Boatwright, K.D. and Jand, J.M. Entrobacteriaceae : Introduction and identification . In P. R. Murray, E. J. Baron, J.H. Jorgensen, M .L.Landry andM.A. Pfaller (eds.), Manual of clinical microbiology, Washington, D. C. , USA , 9th ed . 2007; 649-669.

7. Fraser, S.L. Enterobacter Infections. Medicine.2007.

8. Baron, E.J., Peterson, R. and Finegold, S.M Baily and Scott's. Diagnostic Microbiology. 9th ed. Company. USA. 1994.

9. Holt, J.G., Krieg, N.R., Sneath, P.H.A., Staley, J.T. and Williams, S.T. Bergey's Manual of determination of bacteriology. 9th -ed. Williams \& Wilkins company, USA. 1994.

10. Collee, J.G., Fraser, A.G., Marmion, B.P. and Simmons, A. Practical medical microbiology. 14th ed. Churchill living stone, USA. 11. Mac Faddin, J.F. Biochemical test for identification of medical bacteria, 3rd-ed. William \& Wilkins Co. London. 1996.

11. Kayla, G.S. Alteration in cytokine and chemokine expression during Staphylococcus aureus wound infections. 1994; 130(4): 489-93.

12. Wilson, G.S., Miles, A.M. Principles of bacteriology, virology, and immunity. Williams \& Wilkins, Baltimore. 1975; 876-877.

13. Azza, H.M., Hassan, A.E., Noor El Deen, H.M. Characterization of Enterobacteriaceae Isolated from Cultured Freshwater Fish in Kafr El Shiek Governorate: Clinical, Biochemical and Histopathological Study with Emphasis on Treatment Trials., Global Veterinaria. 2012; 9(5): 617-629.

14. Nazir, K., Rahman, M.B., Khan, M.F.R., Fakhruzzaman, M. Relationship between antibiogram and plasmid profile analysis of Escherichia coli isolate of broiler and layer. $J$ Bangladesh Soc Agric Sci Technol. 2005; 2: 57-60.

15. Temelli, S., Eyigor, A. and Carli, K.T. Salmonella detection in poultry meat and meat products by the Vitek immunodiagnostic assay system easy Salmonella method, a Light Cycler polymerase chain reaction system, and the International Organization for Standardization method 6579. Poult Sci. 2012; 91: 724-31.

16. Landman, W.J., and Cornelissen, R.A. Virulence factors of Escherichia coli, with emphasis on avian pathogenic isolates. Tijdschr Diergeneeskd. 2006; 131: 822-830.

17. Natalia, M., Scott, D.K, Kevin R.B. and Frank, R. Mouse Model of Staphylococcus aureus. Skin Infection. 2013; 245028770.

18. Weinberg, J.M., Mysliwiec, A., Turiansky, G.W. Viral folliculitis: atypical presentations of herpes simplex, herpes zoster, and molluscum contagiosum. Arch Dermatol. 1997; 133: 983986. 